\title{
Jogos e Sociabilidades
}

Nesta edição, a Revista E-Compós contempla um tema de central importância nas sociedades contemporâneas, a relação entre jogos, sociabilidade e comunicação. Do aprendizado lúdico da vida social em jogos tradicionais à indústria de videogames, todas as sociedades, à sua maneira, ensinaram e aprenderam muito com suas brincadeiras. Como já havia salientado Johan Huizinga, em seu clássico Homo ludens, 'toda metáfora é um jogo de palavras': a linguagem e a vida cotidianas estão permeados de ludicidades, que encontram expressão na ideia simmeliana de sociabilidade, forma lúdica da interação social.

0 artigo que abre esta edição é "Imagens da multidão: carnaval e mídia", de Beatriz Jaguaribe, no qual a representação midiática da multidão carnavalesca em diferentes períodos históricos é analisada, evidenciando 0 papel do discurso jornalístico na produção e reprodução de um imaginário sobre as hostes de Momo.

Em seguida, no artigo de Manoel Silvestre Friques, "Troca e Relação na Estética Relacional”, uma abordagem teórica sobre a noção de sociabilidade é empreendida, no contraponto entre as ideias de Marcel Mauss sobre a dádiva como forma relacional e a chamada 'estética relacional' de Nicolas Bourrioud. 
A temática das relações de sociabilidade prossegue com 0 artigo de Alex Damasceno, "A interação entre estranhos no Omegle.com: sociabilidade, relacionamento e identidade", no qual são analisadas as interações ocorrentes em um site de conversações no qual os/as participantes são sempre desconhecidos.

0 recente crescimento dos esportes de combate no universo midiático é analisado no artigo "Da marginalidade ao mainstream: reflexões sobre o MMA (Artes Marciais Mistas) e as sociedades capitalistas contemporâneas", de Fábio de Lima Alvarez e José Carlos Marques. No artigo, os pesquisadores analisam a convergência desta modalidade esportiva com os fluxos informacionais do capitalismo global. A representação midiática do universo do futebol na sociedade brasileira é analisado no artigo "A polifonia discursiva da Copa de 1994: os discursos autorizados sobre o tetracampeonato", de Fausto Amaro e Ronaldo Helal. Neste artigo, a produção discursiva jornalística e acadêmica sobre aquela Copa do Mundo é cotejada, evidenciando as tensões e diferenças entre estas fontes de 'discursos autorizados'.

0 número se encerra com uma entrevista, exclusiva para a E-Compós, do pesquisador argentino Pablo Alabarces, um dos mais importantes nomes das ciências sociais latino-americanas contemporâneas. Alabarces fala sobre os impasses culturais de sociedades periféricas, hooliganismo, imprensa e cultura de torcedores e os megaeventos esportivos no Brasil.

Desejamos a todos/as uma boa leitura. 